\title{
Social Capital: an analytical tool for exploring lifelong learning and community development
}

\author{
SUE KILPATRICK, University of Tasmania \\ JOHN FIELD, Stirling University \\ IAN FALK, Northern Territory University
}

\begin{abstract}
In her recent contribution to the British Educational Research Journal, Pauline McClenaghan identified the link between social capital and community development, particularly community development education, as a core area where scholarly and policy interests overlap. She concluded that the concept of social capital is unable to grapple with the complex social divisions that characterise contemporary Europe. The authors of this article question her account on three main grounds: the definition of social capital, which they hold is overly narrow, and does not deal with what Woolcock calls the 'linking' role of social networks; the presentation of the theoretical foundations of community development, which they believe is flawed in certain key respects; and a lack of clarity in the relationship between the research and the findings reported. The authors then present their own theoretically informed account of social capital as a means of understanding the role of community development, the challenges that it can face and the role of adult education for community development.
\end{abstract}

\section{Introduction}

As the cliché has it, it isn't what you know, but who you know, that counts. The concept of social capital points to the ways in which social relationships serve as a resource, allowing individuals and groups to cooperate in order to achieve goals that otherwise might have been attained only with difficulty, if at all. In recent years, the concept has started to provide a focus for scholarly debate across a wide range of social studies disciplines, and it is now increasingly familiar in policy circles too.

The concept of social capital is unusual in that it is apparently understood across disciplines and by researchers, policy-makers and practitioners. It attracts sociologists, economists, political scientists and historians. It has entered the discourse of national

Received 14 September 2001; resubmitted 12 March 2002; accepted 19 June 2002 
governments and international agencies; the Organisation for Economic Cooperation and Development (OECD, 2001a) report, The Well-being of Nations: the role of human and social capital, is one particularly significant recent example. Similarly, the World Bank has undertaken major research on the role of social capital in reducing poverty in developing countries, and has found measurable economic impacts from social capital (Narayan \& Pritchett, 1997; Krishna \& Uphoff, 1999). Within the European Commission, work on social capital has played a part in shaping regional development policy (Mouqué, 1999).

We should not overstate the degree to which the concept has found acceptance among policy-makers. It commands attention among those who espouse left-of-centre policies more readily than it does among the right or the left. Even policy-makers who are intrigued by its potential tend to be cautious about the concept's practical consequences. The Taoiseach of Ireland, while welcoming the idea as one with 'the potential to be a very positive influence in public policy development in this country and throughout the European Union', immediately qualified this judgement: 'In order to fulfil this potential it has to be used carefully and it requires the attention of a much bigger body of researchers and commentators' (Aherne, 2001, p. 1). Nevertheless, one crucial feature of social capital is that it has enabled considerable dialogue and cooperation among researchers, policy-makers and practitioners from different disciplines (Woolcock \& Narayan, 2000, p. 228). Education and training has been one of the fields most frequently involved, and it is therefore appropriate that the concept should be carefully considered by researchers and others.

\section{A Critique of Social Capital}

In her recent contribution on social capital in the British Educational Research Journal, Pauline McClenaghan identified a core area of analytical debate (McClenaghan, 2000). The link between social capital and community development, particularly community development education, is one where scholarly and policy interests overlap. Her central aim in writing her article is summed up in two passages. In her article:

the validity and usefulness of social capital as an analytical concept in the field of community development adult education research is examined through the exploration of a number of issues relating to the assumed links between community development and social capital enhancement. (2000, p. 566)

Second, she relates the article to 'innovative work' at the University of Ulster examining the 'links between community involvement, informal social learning and participation in formal adult education and the possible implications of these activities for individual and collective opportunity', so that the paper is concerned with 'the validity and efficacy of the social capital concept as a theoretical foundation for this kind of adult education research, based on and informed by insights already emerging from this initial mapping exercise' (p. 567). She then concludes that the current debate over social capital provides a 'relatively weak foundation' for the study of community development (p. 580). While allowing for an exception in the work of Pierre Bourdieu, on balance she judges the concept incapable of grappling with the complex and expanding social divisions and conflicts that characterise contemporary Europe, and rejects it as 'profoundly functionalist and socially conservative' (p. 580).

These are strong claims and significant issues. McClenaghan's critical examination of the relevance of social capital to the theory and practice of community development 
education is to be applauded. However, we believe that her argument is ultimately flawed, and that she has been persuaded to jettison the concept too easily. This article seeks to respond to McClenaghan's critique, and develop an account of social capital which can help explain precisely those features of social relationships that McClenaghan rightly sees as essential to community development, and which may therefore serve in building a theoretical foundation for community development education.

McClenaghan's argument can be summarised as follows. Community development is a broad strategy concerned with mobilising excluded geographic communities (which in Northern Ireland are also divided communities) with the aim of enhancing the economic and human capital potential of the individuals within them. The concept of social capital appears relevant for analysing the effectiveness of community development education in achieving this aim. Yet social capital, as defined and applied in the article, mainly serves to reinforce the power structures and advantages and disadvantages of individuals within these communities. Further, human capital acquired through adult community development education generates opportunities for economic appropriation by its graduates, who use the social capital resource for their own benefit, reinforcing the disadvantage of other community members.

This article seeks to present an alternative view of social capital as a potentially useful analytical tool in community development. We start by questioning McClenaghan's account on three main grounds. First, we challenge her definition of social capital as overly narrow, and argue instead for an approach that encompasses what Woolcock calls the 'linking' role of social networks (Woolcock, 2001, p. 13). Second, we think that her presentation of the theoretical foundations of community development is flawed in certain key respects. Third, we draw attention to a lack of clarity in the relationship between the research and the findings reported. Next, we summarise the theoretical discussion of social capital and social cohesion, and present our hypothesis of the relationship between community development through learning and building social capital. We then present our own theoretically informed account of social capital as a means of understanding both the role of community development and the challenges that it can face.

\section{What is Social Capital?}

There is broad agreement that social capital is a resource based on relationships among people. In particular, most definitions focus on membership in networks and the norms that guide their interactions. These in turn generate secondary features such as knowledge and trust, which then facilitate reciprocity and cooperation. For example, it has been shown that community development approaches which start from an assessment of the networked resources of a community, rather than adopting the more traditional deficit model, and use a participatory approach to project design and implementation have been found to have a more positive impact than traditional approaches (World Bank, 1998; Hibbitt et al., 2001).

However, this apparent widespread understanding disguises a variety of interpretations. Coleman's $(1988,1990)$ and Putnam's $(1993,2000)$ definitions, each based on extensive empirical research, are among the most widely cited. A qualification added by a number of writers, including Putnam, is that the networks and norms are capable of being used for mutual or collective benefit. Others, including Coleman, emphasise the benefits accruing to individuals. This distinction is an important one for operational purposes in community development, so for the purposes of this article we divide these 
approaches into two main groups that can be called 'collective benefit' and 'individual benefit'.

Definitions of the 'collective benefit' type define social capital as:

features of social organization, such as networks, norms, and trust, that facilitate coordination and cooperation for mutual benefit. (Putnam, 1993, p. 35)

[T] he norms and networks that enable people to act collectively. (Woolcock \& Narayan, 2000, p. 226)

[T] he product of social interactions with the potential to contribute to the social, civic or economic well-being of a community-of-common-purpose. (Falk \& Kilpatrick, 2000, p. 103)

Such definitions have sometimes been criticised as being 'communitarian' in nature (Raffo \& Reeves, 2000). However, this is misleading. While communitarian approaches tend to emphasise primordial relationships and ascribed roles-primarily those associated with kinship - social capital theories direct attention towards a diverse variety of different types of relationship, some of them relatively loose and informal. These can include friendship, workplace ties, membership in voluntary associations, participation in social movements, involvement in professional communities of practice and everyday neighbourly interaction.

We distinguish between definitions based on collective benefit and those of Coleman (1988, 1990) and Bourdieu (e.g. 1986), who define social capital as a resource used for the benefit of those individuals who have access to it. In this individual benefit tradition, social capital is represented as:

a particular kind of resource available to an actor ... Unlike other forms of capital, social capital inheres in the structure of relations between actors and among actors. (Coleman, 1988, p. S98)

[T]he aggregate of the actual and potential resources which are linked to possession of a durable network of more or less institutionalized relationships of mutual acquaintance and recognition - or in other words, to membership in a group-which provides each of its members with the backing of the collectivity-owned capital ... The volume of social capital possessed by a given agent thus depends on the size of the network of connections he can effectively mobilize and on the volume of the capital (economic, cultural or symbolic) possessed in his own right by each of those to whom he is connected. (Bourdieu, 1986, pp. 248-249)

Here Bourdieu presents social capital as an attribute of individuals (and therefore of classes) from elite groups. However, he also presents the individual's habitus as a product of social field, and their capital(s) as the combined effects of field and habitus. More simply stated, individuals' knowledge and identities are socially constructed. That Bourdieu's concept of social capital is based on the individual tradition is indicated in the phrase 'possessed in his own right'. However, within this group, it is possible to identify further distinctions. In the neo-Marxist model used by Bourdieu, the social capital resource is mobilised by some actors at the expense of others, representing a 'capital of connections' that is part of a wider set of mechanisms that underpin and reproduce social and economic inequalities. Bourdieu's conceptualisation of social capital does not extend to shared investments and benefits of mutuality. By contrast, 
Coleman's work, situated within the rational actor tradition of the Chicago school, has been more concerned with understanding how individuals come to cooperate in groups in order to advance their individual interests, despite lack of access to other social and economic resources.

\section{External Networks, Cohesiveness and Diversity}

Significant differences follow from the two interpretations. So far as the debate over community development is concerned, there are strikingly different treatments of the role of external networks and the treatment of social cohesiveness, inclusiveness and diversity. In the 'collective benefit' view networks are open; external links are an important part of social capital, as are ties that are elective rather than ascribed (e.g. Flora, 1998; Woolcock \& Narayan, 2000). For example:

our research has identified 'externality' as crucial for developing the positive kinds of interactions that tend to feed the common good. In this case, external interaction is vital to the process, and forms part of our definition of social capital. (Falk \& Kilpatrick, 2000, p. 107)

Networks are most effective for the community as a whole when they are diverse, inclusive, flexible, horizontal (linking those of similar status), and vertical (linking those of different status, particularly local organizations or individuals with external organizations and institutions that have resources not available within the community). (Flora, 1998, p. 490)

McClenaghan rightly notes that social ties can be both blessing and blight, giving rise to costs as well as benefits. Restrictions on recruitment to small firms, as described in Northern Ireland by McClenaghan, can be seen as an example of social ties as a 'blight' from the viewpoint of the employer, in that recruitment of labour based on personal ties can restrict adaptability and limit the scope of labour recruitment (2000, p. 573). However, this insight is already well established in the literature (Woolcock \& Narayan, 2000, p. 226). Putnam devotes a chapter in his most recent study to the 'dark side' of social capital (Putnam, 2000), noting that some people's social capital can have negative consequences for others. Fukuyama (2001) suggests that groups with a 'narrow radius of trust' where 'groups achieve internal cohesion at the expense of outsiders' (p. 9) are more likely to produce negative externalities that affect outsiders, such as corrupt practices, citing the Ku Klux Klan and traditional Indian societies as examples.

However, most analysts believe that the benefits of social capital tend to outweigh the downside. Economists, for example, have identified three broad categories of benefit. First, like any form of social organisation, social capital functions to reduce transaction costs, counter the uncertainties of the market and balance the rigidities of hierarchy (Misztal, 1999; Glaeser et al., 2000). Second, more cohesive societies with high levels of trust are more effective at handling external or internal shocks (Woolcock, 2001, p. 16). Thus, the recruitment practices of Northern Ireland employers can be seen as a rational way of countering the risks from contacts with unknown individuals in a context of internecine conflict (Field \& Spence, 2000). Third, strong networks with well-established expectations of reciprocity can foster the exchange of skills, information and innovation between enterprises who may also compete with one another (Maskell, 2000).

There is, though, substantial disagreement as to precisely how these benefits arise. For Fukuyama (2001), a group's social capital produces positive externalities for outsiders when its radius of trust is larger than the group itself, so that expectations of reciprocity 
and thus the potential for cooperation extend beyond the group. In contrast, Coleman argues that closure of networks gives strength to social capital. Shared norms at home and at school are reinforced by overlapping networks of church and school, generating social capital that translates into superior educational outcomes (Coleman, 1988).

\section{Limitations of the 'Individual Benefit' Definition of Social Capital}

Although broader, 'collective benefit' definitions are acknowledged, McClenaghan's definition of social capital is restricted to the 'individual benefit' tradition. In particular, the scope of networks and ties is limited to what, following Granovetter's early work on labour markets, she refers to as strong, bonding ties, but then lumps these together in an undifferentiated manner as 'traditional' (Granovetter, 1973). 'For the most part it [social capital] is used to refer to norms, values and networks associated with traditional family and community linkages' (McClenaghan, 2000, p. 580). This bonding social capital is contrasted with 'new sets of identities, networks, and values associated with social movements or democratic forms of institutional/civic engagement' (McClenaghan, 2000, p. 580). But these new identities and networks could be interpreted as a new set of bonding ties equally well as weak, bridging ties. And both definitions ignore social capital in other spheres of life, notably work and leisure, spheres where networks and ties are likely to more closely resemble weak bridging or linking ties, as well as being equally important sites for social capital activity.

McClenaghan sees social capital as synonymous with social cohesion:

in all these analyses social capital is used in such a way as to place the main emphasis upon social cohesion; an emphasis which ... discounts community organisation and mobilisation in defence of citizenship rights and the political articulation of rights-based demands which inevitably generate conflict. Such an approach serves only to conceal and obscure the expanding social divisions incorporated within social capital's sister concept, 'community'. (2000, p. 580)

She draws one conclusion from many possible, and this is by no means the only or even dominant approach in the literature. Thus, Tom Schuller acknowledges the close relationship between social capital and social cohesion, but sees social capital as revealing, not concealing, divisions in communities. He suggests that one key reason for exploring the potential of social capital as a policy concept is because its focus on relationships allows the issue of social cohesion to be addressed: "where there is a dark side, this should alert us to the way networks can act against social cohesion' (Schuller, 2001, p. 19).

Many writers have stressed the role of norms that accept diversity and inclusion as elements of social capital, and found these elements to be important in community development. Acceptance of diversity is an indicator of willingness to entertain new ideas and accept change, both prerequisites for community development (Flora et al., 1996). Organisational structures that include representatives of all affected sections of the community, including women, minority and less powerful groups, have been found to be more effective for community development in Europe (Geddes, 1998) and the USA (Aigner et al., 1999).

In McClenaghan's analysis, networks and norms contribute to the reproduction of advantages of certain individuals, and the continued disadvantage of others. Collective norms and values may repress and facilitate the exercise of power (McClenaghan, 2000, p. 573). This raises the issue of the quality of social capital and the nature of the norms 
that are an element of community social capital. It is these finer points regarding the quality of the components of social capital that McClenaghan fails to account for in her analysis and assessment.

We have already noted widespread agreement that social capital is embedded in relationships. McClenaghan argues that bonding ties reduce responsiveness to change (McClenaghan, 2000, p. 573); we hold that it is bridging and linking ties and a norm of inclusion of diversity that foster innovation and responsiveness to change. Bonding ties are an essential first step in the formation and clarification of the shared values and common purposes that shape the nature and scope of a social intervention such as community development (e.g. Kilpatrick et al., 1999). The combination of bonding ties with links that extend beyond the boundaries of the community and norms that include inclusiveness and tolerance and appreciation of diversity that have been associated with community development. We therefore argue that any analysis of community development using a social capital approach must take the broader, 'collective benefit' interpretation of social capital, while allowing for the risk of an (unintended) 'dark side'.

\section{What is Community Development?}

What is community? What is community development? McClenaghan asserts an affinity between social capital and community development, claiming that both are abstractions that denote a 'homogeneous social structure implying common processes in the generation and acceptance of fundamentally positive social norms, values and practices' (italics in original). Her definition explicitly restricts the meaning of 'community development' to 'very specific and empirically grounded communities defined by the concept social exclusion' (p. 571), and she discusses social capital theory in relation to a geographic definition of communities in the North-west of Ireland which are 'deeply fragmented' along religious/ethnic, rural/urban, gender and class divides.

Discussing the community development training programme, McClenaghan herself notes that the course aims to enhance community leadership and build community capacity and networks (2000, p. 571). The particular knowledge and skills, or human capital, that are an expected outcome of community development education are the very knowledge and skills that can be used to promote personal development in others, build networks and set up procedures and structures that enable people to work together for mutual benefit. That is, community development education is expected to foster the building of social capital. It is not clear whether the adult community development course described in McClenaghan's article is intended itself to build social capital that can bridge the various social and cultural divides at local level, or whether its graduates should subsequently be capable of building such bridging social capital. Neither is it clear as to how a social inclusion model of community development could be enacted without engaging other segments of the community, a task that can hardly be achieved by adult community development courses alone.

The practice of community development has long emphasised an inclusive approach to community development that involves all sectors (Kretzman \& McKnight, 1993; Galston \& Baehler, 1995; World Bank, 1998; Hibbitt, Jones \& Meegan, 2001). These approaches include personal development and strengthening of internal and external relationships and networks as well as attitude change toward, for example, inclusion of women and racial minorities or the acquisition of new skills, including leadership. McClenaghan notes that Putnam's work on Italian regions establishes that social capital in the form of horizontal networks and norms of reciprocity and trust are 'a necessary 
precondition for economic development and effective government' (2000, p. 569). This suggests the presence of strong parallels between social capital and the theoretical foundations of community development.

In contemporary conditions, of course, localised divisions are the first rungs of a far-reaching ladder. Does community development require, or should it encourage, 'excluded' communities to change and/or build bridges to allow engagement with other communities and the wider global society? The OECD (2001b, pp. 7-8) and World Bank (see www.worldbank.org/poverty/scapital) research literature suggests that it does. For the international policy bodies, individuals and communities must engage in learning to move from Fordism or agrarian production to the knowledge-based economy. Firms that recruit on the traditional associational, community and kinship ties described by McClenaghan will be at a disadvantage in the new local-global social and economic conditions. Much British and Irish thinking on community development has yet to engage fully with the impact of globalising tendencies and the new structures of governance, yet these are clearly reshaping the immediate context within which geographically bounded communities exist, and are also fostering far-reaching changes in the relations between community and place.

\section{Social Capital and Theories of Community Development}

Whatever else it may or may not be claimed to mean, community development is an intentioned intervention in the lives and directions of community members and community infrastructure. Accountability for community development interventions must be inclusive of disadvantaged groups of people, but also requires a consideration of the balance between broader factors, social, economic and environmental (Holdsworth, 2001). The value of social capital for community development is threefold: it represents both an existing set of resources within the community on which intervention may be based, a 'public good' goal in its own right, and also a resource that can contribute towards sustained autonomous development after the intervention is deemed complete.

In short, McClenaghan falsely links 'social capital' and 'community' as being sister concepts, and applies 'social capital' in a restricted way, finally compounding the logical problem by a narrow concept of 'community development'.

\section{Social Capital as a Set of Resources}

Networks at regional and local level are key mechanisms in productive learning between organisations and individuals. Cooke and Morgan (1998) found that regions that are restructuring, for example, from an outdated industrial base, do so more effectively if they engage in productive learning and adaptation processes through networking. The relationship between industry clusters and economic growth, studied, for example, internationally by Rosenfeld (1995), Maskell (2000) and Porter (1990) and in Australasia by Martinez-Fernandez (1999), Ffowcs-Williams (1997) and Murphy et al. (1997), is attributed largely to the presence of regional interorganisational learning networks. Networks have been found to be instrumental in regional restructuring, such as Uhlir's (1998) study in the Czech Republic, and are a competitive advantage in the knowledgebased economy (Maskell \& Malmsberg, 1999).

Further, recent research using network analysis has found that regions with strong bridging and linking networks between enterprises, community organisations and public organisations are best able to restructure and adapt. One explanation is because of an 
enhanced coordination effect (Martinez-Fernandez, 1999). Another relates to the previously noted positive impact on community and regional sustainability of bridging (or 'weak') ties and linking ties between groups within a community or region and between communities and regions (Granovetter, 1973; Woolcock, 1999; Narayan, 1999). The right mix of the three kinds of ties strengthens the social capital of the community by giving it an external dimension. This enables the community to deal with internal and external problems or changes through access to a wide range of internal and external knowledge, skills and resources.

The operation of regional networks highlights the social embeddedness of the economy (Granovetter, 1985). This can be expected to be even more evident and crucial at community, rather than regional, level. A strong social infrastructure helps rural communities to engage in successful community development, where formal and informal social networks are the basis of social infrastructure (Flora et al., 1997). A number of writers have stressed the capacity of individuals to pool their diverse talents, skills and other assets to solve local problems (Kretzmann \& McKnight, 1993; Miller, 1995; Lane \& Dorfman, 1997). The capacity to share values and interests allows a community to develop strong bonds and a high level of trust among individuals (Bergstrom et al., 1995). This strengthens the entire social network and enables the community to move to develop and resource bridging ties that serve mutual action. This capacity also enables the group to deal with internal and external problems or changes. Partnerships and collaboration bring together people's capacities within communities and mean that a wider range of skills is acquired by people, and this in turn enhances community capacity (Sommerlad et al., 1998; Dickie \& Stewart Weeks, 1999). Social capital can explain the ease with which communities are able to identify, mobilise and combine their human capital, and thus their capacity to change and 'develop'.

An understanding of the processes through which social capital is accessed and built is necessary if social capital is to be used as an analytical tool in the fields of adult education or community development. Social capital can be conceived as being both accessed (operationalised) and built in interactions between individual actors. Falk and Kilpatrick (2000) describe two kinds of social capital resources that are used in interpersonal, one-on-one interactions. They are (1) a knowledge of who, when and where to go for advice or resources and knowledge of how to get things done, called knowledge resources, and (2) identity resources, that is, being able and willing (committed) to act for the benefit of the community and its members. Identity resources include self-confidence, norms such as reciprocity and values, and visions that are shared between the parties to the interaction. Knowledge and identity resources allow community members to combine their skills and knowledge (human capital) with the knowledge and skills of others.

\section{Social Capital Promotes Sustained Autonomous Development}

There are two sorts of positive outcomes possible from interactions that use social capital. One is some action or cooperation for the benefit of the community or its members; the other is the building or strengthening of knowledge and identity resources, such as constructing an agreed, or shared vision for the future. Informal or deliberately arranged interactions help people get to know each other, and develop networks. The interactions can also increase people's confidence to act for the benefit of the community and its members, and build a commitment to members of the community and the community as a whole. Interactions can also have negative outcomes for individuals or 
communities, and can deplete social capital, for example, by reducing confidence or drawing on a norm of exclusion. This is the 'dark side' of social capital in action. Not all interactions have positive or beneficial outcomes for individuals or communities, neither do all interactions build social capital. The quality of the action outcome and the quality of the social capital resources that are built depend on the quality of social capital available and drawn on in interactions.

Flora examines economic development as a form of collective action (1998; Flora et al., 1997) and argues that social capital is a necessary, but not sufficient, condition for community development. He combines a Durkheimian (1984 [1893]) embedded approach that incorporates horizontal networks among internally homogeneous but diverse groups with conflict theory (Collins, 1994). Networks that bridge the diverse groups in a community are crucial. According to Flora et al., other forms of social infrastructure, and by implication, social capital, reinforce the status quo. McClenaghan is thus right in arguing that high levels of social capital do not necessarily guarantee community development. Flora et al.'s incorporation of conflict among diverse groups into an empirically tested theoretical framework that includes social capital should allay McClenaghan's concerns that a social capital framework cannot deal adequately with this issue (2000, p. 580).

We argue that social capital remains a highly appropriate analytical tool for analysing community social assets (particularly relationships, networks, rules and procedures, and norms) and devising strategies for community development. Community development cannot rely solely on the resources present in a community, particularly if the community is defined as homogeneous, excluded and disadvantaged, and coexisting alongside other, separate, homogeneous excluded communities. Adult community development courses that do not take into account the need for embedding the new learning in existing societal structures and institutions will not build social capital, nor have learning outcomes that transfer to other situations. Networks that extend beyond the immediate community to be 'developed' provide access to additional resources, human, physical and financial, to ideas, understandings of rules and procedures for benefiting from opportunities in the wider world.

\section{Community Development Education and Social Capital}

McClenaghan argues in the final sentence of her article that education 'which supports community mobilisation to combat processes of exclusion grounded in [structured capital relations, presumably including human capital]' is vital (2000, p. 580). She argues that the Ulster adult community development education course has failed in this 'mission' (indeed has potentially increased divisions and exclusion), but her article offers no clues about how an alternative course could be structured, or the features it should or shouldn't have. There is, however, an implication in these assertions that because the course has been found to fail in achieving community mobilisation, then somehow social capital has failed as an explanatory device. This is not a logical conclusion that can be derived from the information available. In fact, empirical evidence shows that courses similar to those described by McClenaghan can contribute to social capital in their communities, and to the wider well-being of the regions involved, through the explicit building of interpersonal trust, the conscious build up of bonding ties, and the development of bridging networks from these foundations (Falk et al., 2000).

Social capital for community development must involve 'upscaling'- that is, it must attend to external, bridging and linking networks. Woolcock (2001) asserts that a social 
capital perspective can explain the emergence and persistence of power relations, but more importantly provides a basis for doing something about it. A social capital frame recognises the resources possessed by the excluded groups and holds that these can be used to forge links to institutions dominated by the powerful with the aid of intermediaries. Brokers such as community development practitioners, who can speak the languages of people in the community and people outside, can play an important role in establishing and maintaining internal and external ties (Kilpatrick \& Bell, 1998) and developing shared visions about the preferred future of the community that can act as a blueprint for action. Community development practitioners who are community members with an adult education qualification as a foundation for their practice should be especially well placed to act as brokers.

\section{Relationship of Research to Findings}

Much research into community development education has tended to be stronger on prescription and exhortation than empirical investigation. Consequently, there is relatively little evidence of its impact upon social capital. Although McClenaghan's article repeatedly refers to data from a study of a community development course in Derry, and the evaluation method is briefly described, the research design is not discussed and the findings themselves are not systematically presented. It is not clear what outcomes there have been for the social capital of individual participants, their groups or communities. Moreover, at times the interpretation seems contradictory. We are told that evidence from the research suggests that in disadvantaged communities in Northern Ireland and elsewhere " "downward levelling pressures" may act to undermine individual adult aspirations to rise above current personal circumstances through formal learning' (McClenaghan, 2000, p. 574), even though 'the majority of students have been drawn from [communities] ... which have been socially marginalised by high unemployment.' (2000, p. 574). It is not easy to reconcile this hypothesis with the statement that ' $65 \%$ of students progressed to higher education on completion of the course' (2000, p. 575), and were therefore 'lost' to their communities.

Such difficulties make it hard to judge evidence-based claims in McClenaghan's argument. There are indicators in the article that social capital, defined according to the 'collective benefit' view, is built by the adult community development course. On page 575 we are told that "voluntary participation rates in community sector activity among students increased quite substantially' and that participation had 'broadened to include a wider range of voluntary activity', appearing to indicate an increase in social capital resources. On page $575 \mathrm{McClenaghan}$ also notes that 'levels of confidence and perceptions of personal effectiveness had also increased', although a 'lack of confidence and self-esteem expressed by students' is noted on the following page. Self-confidence is associated with social capital and is essential if people are to be willing and able to act on behalf of others (Falk \& Kilpatrick, 2000). Kilpatrick et al. (1999) have examined the process by which formal learning situations develop social capital and noted that personal development is a stage in that process. The fact that 'students and their peers identified important contributions made to group developments' (McClenaghan, 2000, p. 575) illustrates that the adult community development students were able to work effectively with others to produce outcomes that appear to be beneficial for the collective. Our interpretation of these findings presented by McClenaghan is that the adult community development course builds human capital that in turn builds "norms and 
networks that enable people to act collectively' (Woolcock \& Narayan, 2000, p. 226); that is, social capital as defined by the 'collective benefit' view.

McClenaghan is concerned that the adult community development course is damaging social ties within close-knit communities, describing her findings as 'more reflexive, perhaps, of Granovetter's weak ties than Coleman's relatively closed structure' (2000, p. 576). But the evidence presented suggests that the nature of the community groups themselves may be at least partly responsible. The groups provide financial and affective support that enables potential students to achieve their 'aspirations for self-improvement and the acquisition of recognised and accredited qualification' (2000, p. 576), and continues to be important in the social networks of past students through voluntary participation and employment (p. 575). The groups have provided the students with additional sets of social relationships. The students now have bridging ties that should complement their close bonding ties. Further, marketisation and contracting arrangements have drawn community groups into partnerships and other arrangements with institutions such as local authorities and other bureaucracies (McClenaghan, 2000, p. 578). In theory at least, these provide access to powerful networks outside the community. But McClenaghan asserts that the new relationships have displaced, not complemented, the old, reporting 'fear of ridicule and censure by their peers outside the confines of the community groups of which they are now a part' (2000, p. 576). This evidence hints at a particularly inward-looking culture within the groups, possibly in response to the risks of violence in working-class urban neighbourhoods in Northern Ireland.

\section{Social Capital Theory and Social Cohesion}

McClenaghan's assertion raises important questions: can new weak or bridging ties be developed without breaking down existing social ties in close-knit communities? Do upscaling networks in disadvantaged communities inevitably diminish the previously strong bonding ties that allowed people to 'get by' (Woolcock, 2001)? Must a community forgo some of its internal bonds if it wants to have a mix of bonding, bridging and linking ties that will enable it to deal with internal and external problems or changes through access to a wide range of internal and external knowledge, skills and resources (Woolcock, 1999; Narayan, 1999)?

The discussion here is about social capital in the context of community development and learning (particularly formal education). It is therefore appropriate to consider how the processes of community development and learning might differently affect social capital associated with bonding and bridging ties. We have already noted that social capital is both accessed and built in interactions between individual actors. Consideration of the process of community mobilisation from the viewpoint of the individual actor may help in understanding how learning can be a process that changes norms and identity, and develops new ties.

McClenaghan rightly states that social mobilisation underpinned by demands based on rights involves new ways of seeing one's identity and is likely to 'challenge these [existing] ties and their implicit normative systems in favour of new forms of association and new ways of perceiving social relations' (2000, p. 577). That is, the informal learning arising from participation in social movements tends to alter existing bonding ties and associated social capital while establishing new ties and associated social capital. The new ties could be regarded as binding members into the social movement. The alternative conceptualisation of the new ties and associated norms as bridging between 
established groups is undermined by McClenaghan's suggestion that existing ties are being abandoned in favour of new forms of association. She asserts that the ties built in social movements are 'a long way from the traditional associational ties, the decline of which are lamented as a "public loss", (2000, p. 577). McClenaghan earlier indicates a preference for rebuilding community 'as a process of political mobilisation to advance demands based on rights' (italics in original) over 'a social process of coordination aimed at developing and enhancing social cohesion' which risks reinforcing exclusion (2000, p. 572). This assumption that bridging ties are necessarily separate from and in conflict with bonding ties is confusing and inaccurate.

There is no simple binary division between either existing social capital associated with traditional ties or new social capital. Norms and identities of individuals and communities are dynamic. Previous research (e.g. Kilpatrick et al., 1999, Falk \& Kilpatrick, 2000) shows that they are constantly challenged through learning processes and can be either retained, adapted or rejected in the face of alternative norms and values. Nor are social movements intrinsically associated with new bridging ties. Some types of social movement-including nationalisms of different colours as well as fundamentalist religious groupings - are more or less deliberately based on and designed to reinforce traditional ties, particularly when these are precariously balanced against 'the (potentially) universal function of the market' (Zizek, 1997, p. 42).

\section{Balancing Bonding and Bridging Ties through Learning}

Our hypothesis is as follows. If researchers such as Woolcock are right in saying that social capital is stronger, and so more effective in improving outcomes for communities, when there is a mix of bonding and bridging ties, then a process of community development through informal learning associated with social mobilisation is capable of increasing the stocks of individual and community social capital, despite some weakening (or diffusion) in bonding social capital, or diffusion with bridging social capital. Learning through formal education has also been found to increase stocks of social capital. Education influences the breadth, depth and richness of networks and produces skills in relating to others, such as making friends and conflict resolution, and a generalised feeling of self-confidence, all aspects of social capital resources (StantonSalazar, 1998). This is consistent with McClenaghan's findings reported on page 575 of wider associations, increased self-confidence and effective contributions to group developments. Stanton-Salazar notes that educational attainment is more significant in building social capital for working-class people, whose networks are bounded, smaller, more homogeneous and have little reach into institutions and networks of what StantonSalazar terms 'the mainstream'. This could be interpreted as saying that formal education helps working-class people build bridging ties.

Years of formal education are widely found to be correlated with social capital variables, such as membership in organisations and trust, for individuals and communities (Glaeser, 2001). Some researchers go so far as to use parents' years of education as a proxy for family social capital (for example, Willms, 2001). This quantitative work does not distinguish between social capital that is attributable to close, or bonding ties, and that attributable to weak bridging and linking ties.

It is possible that 'too much' education (human capital) may reduce social capital associated with bonding ties. Putnam (2000) and Coleman (1988) have both concluded that high levels of family human capital may be associated with higher mobility, longer working hours and consequently reduced time for social interaction within the family 
and between the family and other social networks, which is consistent with lower 'bonding' social capital. It may be that the weakening of traditional bonding ties experienced by the students in McClenaghan's study is partly attributable to having less time for family and close friends.

In summary, we hold that the scant research findings reported by McClenaghan are interpreted against a narrow 'individual benefit' view of social capital, whereas the 'collective benefit' view is a more appropriate and empirically supportable social capital frame for analysing community development and learning (informal or formal) that might assist in community development. The choice of frame means that issues of balance between bonding, bridging and linking ties, and the key part played in the collective benefit view by reciprocity and norms that are inclusive, are ignored. Social capital is rejected as an adequate analytical tool, despite evidence that the community development course has developed resources that many consider to be social capital, and that these have been used in 'important contributions made to group developments' (McClenaghan, 2000, p. 575). Fundamentally, it seems to us that she is using her course as a proxy for something that builds social capital, finds the course fails, then blames social capital!

\section{A Social Capital Framework for Analysing Community Development}

A social capital framework can be used to analyse the resources present in a community that are available for use in community development. It can identify strengths and weakness, or areas where intervention can improve the community's social capital resources. The framework we propose can also be used to evaluate the success of an intervention strategy. We suggest that a social capital framework to analyse community development, including adult education, should consider:

- the balance between internal and external networks. Bonding networks are a necessary but insufficient component of social capital. Networks extending outside the community are of two types: bridging networks (these could be with other communities or among professionals working in community development) and linking networks with people or institutions at other levels of power;

- the presence and diversity of brokers who are able to operationalise the bridging and linking networks;

- the levels of self-confidence and self-esteem of community members and skills in working together, including conflict resolution;

- norms present in the community, especially norms of inclusion/exclusion and reciprocity;

- the extent to which the community of analysis has shared visions for its future.

Our framework does not specify quantitative bands of networks or brokers, or how any weaknesses identified should be remedied. Each community or intervention to be analysed is different, will have different needs and a different complex set of relationships, often shaped by past histories. The threats and opportunities and types of changes required for communities to move toward their preferred vision for the future will vary from community to community. The framework focuses on the nature of relationships rather than what could be termed the interactional infrastructure of the community. Interactional infrastructure includes opportunities to meet/associate with others within and outside the community of analysis, indicating the presence of networks and the rules and procedures operating in a community. It may be possible to alter networks or norms 
by changing the interactional infrastructure. McClenaghan's description of the support provided by the community groups which her students joined is an illustration of interactional infrastructure which facilitated new networks and increased confidence and self-esteem.

\section{Conclusion}

There are strong parallels between developing social capital and community development. Our examination of the literature in the light of McClenaghan's discussion leads us to conclude that social capital resources are useful in the process of community development and that the process of building social capital can be part of a community development process. The factors that lead us to embrace social capital as an analytical tool when McClenaghan rejects it stem from our conclusion that the theoretical foundations of community development align with a 'collective benefit' (e.g. Putnam, 1993; Woolcock \& Narayan, 2000; Falk \& Kilpatrick, 2000), not 'individual benefit' (e.g. Bourdien, 1986; Coleman, 1988), view of social capital. Thus, community development should be analysed by considering external, bridging and linking networks as well as within-community bonding networks, and norms of inclusion and acceptance of diversity as well as norms that exclude and foster social cohesion only if communities are homogeneous.

The 'dark side' of social capital (Putnam, 2000; Schuller, 2001) with its negative normative associations and norms of exclusion should be part of any analytical framework based on social capital. This perspective helps identify weaknesses in the social capital resources of a community that could be useful in community development, including imbalances in power and areas of unproductive conflict. As Woolcock (2001) suggests, a social capital perspective also provides a base for identifying existing resources that could be used to do something about weaknesses and the nature of external resources that may complement these existing resources.

Social capital is an appropriate analytical framework for diagnosing the strengths and weaknesses of the social assets of a community (whether defined by geography or common purpose), and identifying aspects where intervention, for example, by community development practitioners, could usefully build community capacity to manage change and develop. Community development is a process; social capital is a set of resources which can be changed through various processes, including community development. Community development as supporting the collective to act to address common needs is entirely consistent with building social capital resources, and can be analysed using a social capital framework.

Correspondence: Sue Kilpatrick, Centre for Research and Learning in Regional Australia, University of Tasmania, Locked Bag 1313, Launceston, Tasmania 7250, Australia; e-mail: Sue.Kilpatrick@utas.edu.au

\section{REFERENCES}

AHerne, B. (2001) Social capital: lessons for public policy development, Speech to Seminar on Social Capital, Dublin Castle, 29 March 2001.

Aigner, S., Flora, C. \& Hernandez, J. (1999) The Premise and Promise of Citizenship and Civil Society 
for Renewing Democracies and Empowering Sustainable Communities (Edinburgh, International Association of Community Development).

Bergstrom, A., Clark, R., Hogue, T., Perkins, D. \& Slinski, M. (1995) Collaboration Framework: addressing community capacity (University of New Mexico, National Network for Collaboration).

Bourdieu, P. (1986) The forms of capital, in: J. RichARDSON (Ed.) Handbook of Theory and Research for the Sociology of Education (Westport, CT, Greenwood Press).

Coleman, J. (1988) Social capital in the creation of human capital, American Journal of Sociology, 94, Supplement, pp. S95-120.

Coleman, J. (1990) Foundations of Social Theory (Cambridge, MA, Belknap Press).

Collins, R. (1994) Four Sociological Traditions (New York, Oxford University Press).

Cooke, P. \& Morgan, K. (1998) The Associational Economy: firms, regions and innovation (Oxford, Oxford University Press).

Dickie, M. \& Stewart Weeks, M. (1999) Presentation on the national marketing strategy for skills and lifelong learning, ANTA Training Update Seminar Keynote Address: http:;dRwww.anta.gov.au/ anta_prod/EVENTS/TUS_NOV99/papers.htm

Durkheim, E. (1984 [1893]) The Division of Labor in Society (New York, The Free Press).

Falk, I., Golding, B. \& Balatti, J. (2000) Building Communities: ACE, lifelong learning and social capital (Melbourne, Language Australia).

FALK, I. \& Kilpatrick, S. (2000) What is social capital? A study of a rural community, Sociologia Ruralis, 1(40), pp. 87-110.

FFOWCS-WILLIAMS, I. (1997) Local clusters and local export growth, New Zealand Strategic Management, 1(3), pp. 24-30.

Field, J. \& Spence, L. (2000) Social capital and informal learning, in: F. Coffield (Ed.) The Necessity of Informal Learning (Bristol, Policy Press).

FlORA, J. (1998) Social capital and communities of place: presidential address, Rural Sociology, 63, pp. 481-506.

Flora, C. B., Flora, J. \& Wade, K. (1996) Measuring success and empowerment, in: N. Waltzer Community Strategic Visioning Programs (London, Praeger).

Flora, J., Sharp, J., Flora, C. \& Newlon, B. (1997) Entrepreneurial social infrastructure and locally initiated economic development in the non-metropolitan United States, Sociological Quarterly, 38, pp. 623-645.

Fukuyama, F. (2001) Social capital, civil society and development, Third World Quarterly, 22, pp. 7-20.

Galston, W. \& Baehler, H. (1995) Rural Development in the United States: connecting theory, practice and possibilities (Washington, DC, Island Press).

GedDEs, M. (1998) Local Partnership: a successful strategy for social cohesion? (Dublin, European Foundation for Improvement of Living and Working Conditions).

Glaeser, E. (2001) The formation of social capital, Isuma: Canadian Journal of Policy Research, 2, pp. 34-40.

Glaeser, E., Laibson, D., Scheinkman, J. \& Soutter, C. (2000) Measuring trust, Quarterly Journal of Economics, 115, pp. 811-846.

Granovetter, M. (1973) The strength of weak ties, American Journal of Sociology, 78, pp. 1360-1380.

GranovetTER, M. (1985) Economic action and social structure: the problem of embededness, American Journal of Sociology, 91, pp. 481-510.

Hibittt, K., Jones, P. \& Meegan, R. (2001) Tackling social exclusion: the role of social capital in urban regeneration on Merseyside, European Planning Studies, 9, pp. 141-161.

Holdsworth, L. (2001) The new ethics of leadership, Chartered Accountants Journal of New Zealand, 80(3), pp. 6-8.

KILPATRICK, S. \& BELL, R. (1998) Review of Research ... VET for people from rural/non metropolitan areas (Adelaide, National Centre for Vocational Education Research).

KilPatrick, S., Bell, R. \& FAlK, I. (1999) The role of group learning in building social capital, Journal of Vocational Education \& Training, 51, pp. 129-144.

Kretzmann, J. \& McKnight, J. (1993) Building Communities from Inside Out: a path toward finding and mobilizing a community's assets (Chicago, IL, ACTA Publications).

Krishna, A. \& Uphoff, N. (1999) Mapping and Measuring Social Capital: a conceptual and empirical study of collective action for conserving and developing watersheds in Rajasthan, India, Social Capital Initiative Working Paper No. 13 (Washington, World Bank).

Lane, B. \& Dorfman, D. (1997) Strengthening Community Networks: the basis for sustainable community renewal (Portland, Northwest Regional Educational Laboratory). 
MARTINEZ-FERnANDEZ, C. (1999) The network perspective in regional regeneration: an organic analysis of the Hunter Regional Network for Economic Development, paper presented at 23rd Annual Conference of the Australia and New Zealand Regional Sciences Association International, Newcastle, Australia, 19-22 September.

MAskell, P. (2000) Social capital, innovation and competitiveness, in: S. BARON, J. FIELD \& T. SCHULLER (Eds) Social Capital: critical perspectives, pp. 111-23 (Oxford, Oxford University Press).

Maskell, P. \& Malmberg, A. (1999) Localised learning and industrial competitiveness, Cambridge Journal of Economics, 23, pp. 167-168.

McClenaghan, P. (2000) Social capital: exploring the theoretical foundations of community development education, British Educational Research Journal, 26, pp. 565-582.

MiLlER, B. (1995) The role of rural schools in community development: policy issues and implications. Available at: http:;dRwww.nwrel.org/ruraled/Role.html

MiszTal, B. A. (1999) Informality: social theory and contemporary practice (London, Routledge).

Mouqué, D. (1999) Sixth Periodic Report on the Social and Economic Situation and Development of the Regions of the European Union (Brussels, European Commission).

Murphy, P., Pfister, N. \& Wu, C. T. (1997) Industry Cluster Strategies for Regional Economic Development (Lismore, Australia, CARED, Southern Cross University).

NARAYAn, D. (1999) Bonds and Bridges: social capital and public policy, Policy Research Working Paper 2167 (Washington, World Bank).

Narayan, D. \& Pritchett, L. (1997) Cents and Sociability: household income and social capital in rural Tanzania, Policy Research Working Paper 1-41 (Washington, World Bank).

ORgANiSATION FOR ECONOMic COOPERATION AND DEVElopment (OECD) (2001a) Well-being of Nations: the role of human and social capital (Paris, OECD).

Organisation fOR ECONOMIC COOPERATION AND DEVElOPMENT (OECD) (2001b) Cities and Regions in the New Learning Economy (Paris, OECD).

Porter, M. (1990) The Competitive Advantage of Nations (London, Macmillan).

Putnam, R. (1993) Making Democracy Work: civic traditions in modern Italy (Princeton, NJ, Princeton University Press).

Putnam, R. (2000) Bowling Alone: the collapse and revival of American community (New York, Simon \& Schuster).

RAFFo, C. \& ReEves, M. (2000) Youth transitions and social exclusion: developments in social capital theory, Journal of Youth Studies, 3, pp. 147-166.

Rosenfeld, S. (1995) Industrial Strength Strategies: regional business clusters and public policy (Washington, The Aspen Institute).

SCHULler, T. (2001) The complementary roles of human and social capital, Isuma: Canadian Journal of Policy Research, 2, pp. 18-24.

Sommerlad, E., Duke, C. \& Mcdonald, R. (1998) Collaboration in the Emerging World of 'Universal Higher Education' (Canberra, Higher Education Council).

Stanton-Salazar, R. (1998) Defensive network orientations as internalised oppression: how schools mediate the influence of social class on adolescent development, in: B. BIDDLE (Ed.) Social Class, Poverty \& Education, vol. 3 Missouri Symposium on Research and Educational Policy (New York, Garland).

UHLIR, D. (1998) Internationalization, and institutional and regional change: restructing post-communist networks in the region of Lanskroun, Czech Republic, Regional Studies, 32, pp. 673-685.

WiLlms, J. (2001) Hypotheses about community effects on social outcomes, Isuma: Canadian Journal of Policy Research, 2, pp. 53-62.

Woolcock, M. (1999) Managing risk, shocks and opportunity in developing economies: the role of social capital (unpublished paper) (Washington DC, Development Research Group, World Bank).

Woolcock, M. (2000) Managing risk, shocks and opportunity in developing economies: the role of social capital, in: G. RANIS (Ed.) Dimensions of Development (New Haven, CT, Yale Center for International and Area Studies).

Woolcock, M. (2001) The place of social capital in understanding social and economic outcomes, Isuma: Canadian Journal of Policy Research, 2, pp. 11-17.

WoOlCock, M. \& NARAYAN, D. (2000) Social capital: implications for development theory, research and policy, World Bank Research Observer, 15, pp. 225-249.

World BANK (1998) The Initiative on Defining, Monitoring and Measuring Social Capital: overview and program description, Social Capital Initiative Working Paper No. 1 (Washington, DC, World Bank Social Development Family Environmentally and Socially Sustainable Development Network).

ZIZEK, S. (1997) Multiculturalism, or, the cultural logic of multinational capitalism, New Left Review, 225, pp. 28-51. 
